\title{
A NOTE ON STYLE
}

SHORT TITLEs for various volumes of the Works are ordinarily used in the text, for example, Central America I for the History of Central America, volume I. In the same manner, the History of the Pacific States is frequently abbreviated to History.

Bancroft's collection is referred to as the Bancroft library until its sale to the University of California. The Bancroft Library is used to designate the institution within the University. Directly quoted material may show exceptions to this rule. 